\title{
Wastewater Treatment Using Alum, the Combinations of Alum-Ferric Chloride, Alum-Chitosan, Alum-Zeolite and Alum- Moringa Oleifera as Adsorbent and Coagulant
}

\author{
Ahmad Hussaini Jagaba ${ }^{1}$, Sule Abubakar ${ }^{1}$, Ibrahim Mohammed Lawal ${ }^{1}$, Ab Aziz Abdul Latiff ${ }^{2}$, \\ Ibrahim Umaru ${ }^{1}$ \\ ${ }^{1}$ Department of Civil Engineering, Abubakar Tafawa Balewa University, Bauchi, Nigeria \\ ${ }^{2}$ Department of Water Resources and Environmental Engineering, University Tun Hussein Onn Malaysia, Batu Pahat, Malaysia
}

Email address:

ahjagaba@atbu.edu.ng (A. H. Jagaba), absadiqq@gmail.com (S. Abubakar), Ubawo04@yahoo.com (I. M. Lawal), aziz@uthm.edu.my (Ab A. Abdul Latiff), ibropopoi@yahoo.com (I. Umaru)

\section{To cite this article:}

Ahmad Hussaini Jagaba, Sule Abubakar, Ibrahim Mohammed Lawal, Ab Aziz Abdul Latiff, Ibrahim Umaru. Wastewater Treatment Using Alum, the Combinations of Alum-Ferric Chloride, Alum-Chitosan, Alum-Zeolite and Alum- Moringa Oleifera as Adsorbent and Coagulant. International Journal of Engineering Management. Vol. 2, No. 3, 2018, pp. 67-75. doi: 10.11648/j.ijem.20180203.13

Received: October 30, 2018; Accepted: November 19, 2018; Published: December 17, 2018

\begin{abstract}
Aluminium sulphate (alum), an inorganic salt, is the most widely used coagulant in wastewater treatment, due to its proven performance, cost-effectiveness and availability. However, the use of aluminium-based coagulant has become under scrutiny. Besides the large amount of sludge produced, high level of aluminium remaining in the treated water has raised concern on public health. Previous research has pointed out that the intake of large amount of aluminium salt may contribute to the development of neurodegenerative diseases. To reduce the large intake of aluminium salt in the treatment of palm oil mill effluent (POME), this research examined the comparative suitability of alum and combinations of alum as the primary coagulant with other coagulants (ferric chloride, zeolite, chitosan and moringa oleifera) for the treatment of (POME) at optimum conditions of both coagulants. It also ascertain which combined coagulants with alum and an anionic polymer has the potential for higher pollutants removal. Results obtained revealed that, addition of $1 \mathrm{~g} / \mathrm{L}$ of ferric chloride, $0.4 \mathrm{~g} / \mathrm{L}$ chitosan and $1 \mathrm{~g} / \mathrm{L}$ zeolite each to different dose of alum, were able to reduce alum dose from $4 \mathrm{~g} / \mathrm{L}$ to $2 \mathrm{~g} / \mathrm{L}, 3 \mathrm{~g} / \mathrm{L}$ and $2 \mathrm{~g} / \mathrm{L}$. However, 2 $\mathrm{g} / \mathrm{L}$ moringa oleifera addition could not reduce alum dose as high removal efficiencies for most parameters were obtained at 4 $\mathrm{g} / \mathrm{L}$ alum $+2 \mathrm{~g} / \mathrm{L}$ moringa oleifera.
\end{abstract}

Keywords: Aluminium Sulphate, Coagulation, Flocculation, Heavy Metals, Wastewater

\section{Introduction}

In spite of a relatively positive environmental record, Malaysia faces problems which can be attributed to deforestation, discharge of pollutants into rivers, lands and air, overfishing and coral reef destruction, along with air and water pollution thereby making the environment unhealthy for living organisms. Malaysia has enjoyed one of the least polluted urban environments in Asia. However, with the massive industrial development of recent years, and an increase in urbanisation that attributed to increase in agricultural practices and vehicular use resulting to various types of pollutants such as solid waste, hazardous waste, toxic and liquid waste, water and air pollution are of growing concern [1].

Water pollution still poses a serious threat in certain parts of Malaysia. Studies show that the major contributors to water pollution are agriculture, agro-based industries such as palm oil processing industries, rubber processing industries, food and beverage processing plants, textile and leather tanneries, and electronic hardware factories, many of which discharge effluents directly into rivers. Uncontrolled release of the pollutants into the air during manufacturing processes of palm oil has led to an unstable environmental threat [2]. Some negative effects of these pollutants worldwide are depletion of ozone layer, global warming and significant raise of ocean level.

Malaysia, like other developing countries had achieved an 
outstanding performance of economic growth since implementing mass industrial revolution. One of big and outstanding industries in Malaysia is agricultural based oil palm industry. The production of palm oil generates large amounts of polluted wastewater known as palm oil mill effluent (POME). Palm oil industries worldwide are facing significant challenges in meeting the increasingly stringent environmental regulations on the disposal of POME. The raw or partially treated POME has an extremely high content of degradable organic matter, which is due in part to the presence of unrecovered palm oil. This highly polluting wastewater can, therefore, cause pollution of waterways due to oxygen depletion and other related effects as reported by [3]. Thus, while enjoying a most profitable commodity, the adverse environmental impact from the palm oil industry cannot be ignored.

Palm oil industry produces palm oil mill effluent (POME) which becomes one of the major sources of water pollution containing toxic substances, harmful bacteria and unwanted solid waste which can be classified as organic or inorganic. To mitigate the effect of these effluents and also balance economic growth with environmental protection, the Malaysian government enact the Environment Quality Act, 1974 under the Department of Environment (DOE) which is a comprehensive law on environmental management in Malaysia and specific regulations for palm oil mill effluent in 1975. This act was later amended to [4]. Under this act, it is mandatory for all palm oil mills to treat their wastewaters on site to an acceptable level or convert them into by-products with added value before they are allowed to be discharged into water ways [5].

The enactment of the environment regulations in 1975 , concerted and intensive research and development programs initiated by both the public and private sectors to find costeffective solutions in minimizing the environmental impact of the palm oil industry. Wastewater treatment capability is one of the most important components in the palm oil production. This capability is normally used to treat a large volume of POME generated during the production of CPO before the effluent is safely discharged to the surrounding environment through water canal or river which affects the natural environment and creates a major ecological problem throughout the world [6].

Most of industrial wastewater can lead to severe problems in different treatment stages, current methods for such wastewater treatment include coagulation-flocculation, sedimentation, filtration, membrane and biological processes. Each one of these methods has its advantages and disadvantages. Among the current methods, coagulationflocculation process is one of the most effective methods widely used in wastewater treatment [7].

Treatment of POME by coagulation-flocculation within a short period of time without involving a vast area of land may offer a cost-effective solution to negative environmental impacts as a result of untreated POME discharged to the environment. The use of chemicals, herbs, seafood, and some geological materials in the treatment of wastewaters has been reported to be successful by many researchers [8].

In order to reduce the negative effects of inorganic salts during and after the treatment of POME, aluminium sulphate (alum) would be partially replaced by zeolite, ferric chloride, moringa oleifera and chitosan. The capability of alum and its partial replacement with these other coagulants in POME treatment via coagulation-flocculation process would then be investigated.

\subsection{Comparison Between Commercial Coagulants (Alum \& $\mathrm{FeCl}_{3}$ ) in Terms of Parameter Removal}

Coagulation by hydrolysing metal salts, typically of iron $(\mathrm{Fe})$ or aluminium $(\mathrm{Al})$, is the main reaction stage that drives the removal of natural organic matter (NOM) and other contaminants in potable water treatment [9]. The species distribution of $\mathrm{Al}$ (III) and $\mathrm{Fe}$ (III) in aluminum coagulants and iron coagulants has significant effects on its coagulation efficiency, floc properties, and contaminant removal efficiency. Previous research has indicated that $\mathrm{Al}$ has been the most effective polymeric $\mathrm{Al}$ species in water and wastewater treatment, the separation and purification of which mainly includes the $\mathrm{SO}_{4} / \mathrm{Ba}^{2+}$ deposition-replacement method, ethanol-acetone precipitation method, the ultrafiltration method and column chromatography method. Aluminium sulphate $\left[\mathrm{Al}_{2}\left(\mathrm{SO}_{4}\right)_{3} \cdot 16 \mathrm{H}_{2} \mathrm{O}\right]$ with a molecular weight of $598.4 \mathrm{~g} / \mathrm{mol}$ and Ferric chloride $\left[\mathrm{FeCl}_{3}\right]$ with a molecular weight of $162 \mathrm{~g} / \mathrm{mol}$ are commonly used coagulants and were used in this study where the reduction efficiency of turbidity, $\mathrm{COD}, \mathrm{TSS}, \mathrm{NH}_{3}-\mathrm{N}$, oil and grease. colour, and heavy metals ( $\mathrm{Fe}, \mathrm{Pb}, \mathrm{Cu}, \mathrm{Mn}, \mathrm{Cd}$ and $\mathrm{Zn}$ ) were the main evaluating parameters.

\subsection{Comparison between Natural Coagulants (Chitosan, Zeolite and Moringa Oleifera) in Terms of Parameter Removal}

In recent years, chitosan and moringa oleifera have been applied as coagulants in water treatment [10]. Chitosan is a partially deacetylated polymer obtained from the alkaline deacetylation of chitin, a biopolymer extracted from shellfish sources. Chitosan with a molecular weight of $1,526.454 \mathrm{~g} / \mathrm{mol}$ exhibits a variety of physico-chemical and biological properties resulting in numerous applications in fields such as cosmetics, biomedical engineering, pharmaceuticals, ophthalmology, biotechnology, agriculture, textiles, oenology, food processing and nutrition. This aminobiopolymer has also received a great deal of attention in the last decades in water treatment processes for the removal of particulate and dissolved contaminants. In particular, the development of chitosan-based materials as useful coagulants and flocculants is an expanding field in the area of water and wastewater treatment. Their coagulation and flocculation properties can be used to remove particulate inorganic or organic suspensions, and also dissolved organic substances [11].

The protonization of amino groups in solution makes chitosan positively charged, and thereby very attractive for 
flocculation and different kinds of binding applications. Since most natural colloidal particles including bacteria and macromolecules, are negatively charged, attractive electrostatic interactions may lead to flocculation [12]. The main parameters influencing the characteristics and properties of chitosan are its molecular weight (MW), degree of deacetylation (DD), representing the molar fraction of deacetylated units, and crystallinity. These parameters are determined by the conditions set during preparation [13].

Natural macromolecular coagulants extracted from plants such as moringa oleifera seed, Jatropha curcas, copra and Cactus etc. are promising and have attracted a lot of attention due to their advantages such as abundant source, low toxicity, multi-purposeness and bio-degradability [14]. In particular, Moringa oleifera seed has been regarded as one of the best natural products for water treatment. It has been reported that moringa oleifera seed can be used to remove many pollutants including turbidity, heavy metals, Escherichia coli, algae, surfactants from water [15]. The cationic proteins in moringa oleifera seed have been proved to be the active components for water treatment [16]. Adsorption and neutralization of charges are the main mechanisms of coagulation. It is possible to extract an edible vegetable oil from the moringa seeds before using as the coagulant. In coagulation, moringa hardly affects the $\mathrm{pH}$ and conductivity. Therefore, the application of moringa oleifera seeds in wastewater treatment can reduce the cost of chemicals used for $\mathrm{pH}$ adjustment. The volume of sludge produced using Moringa as coagulant is considerably less compare to alum and do not offer any disposal problem [17].

The use of clay mineral has undoubtedly become more popular and widely used as an adsorbent and ion exchange for water and wastewater treatment applications especially for removing heavy metal, organic pollutants, and nutrients [18]. Clay minerals, such as bentonite and zeolite, are some of the potential alternatives, as they have large specific surface areas with a net negative charge, which can be electrically compensated for by inorganic and organic cations from the environment compared to polyaluminium chloride. Their sorption capabilities come from their high surface areas and exchange capacities. It is a highly effective natural clay mineral, especially in granular form, used for the purification of wastewater and sludge dewatering [19]. Zeolite used in this study has a molecular weight of $2190 \mathrm{~g} / \mathrm{mol}$.

\section{Materials and Method}

\subsection{Materials}

Raw palm oil mill effluent was collected from Pertubuhan Peladang Negeri Johor (PPNJ) Oil Palm Mill, Kahang, Johor Darul Takzim, Malaysia. Alum $\left(\mathrm{Al}_{2}\left(\mathrm{SO}_{4}\right)_{3} \cdot 18 \mathrm{H}_{2} \mathrm{O}\right)$, ferric chloride, chitosan, zeolite and moringa oleifera were used without any further modifications. Distilled water was used to dilute hydrochloric acid and dissolve sodium hydroxide pellets to obtain solutions with a concentration of $1 \mathrm{~mol} / \mathrm{L}$. The prepared acid and base solutions were used to adjust the initial $\mathrm{pH}$ of treatment process.

\subsection{Characterization of POME}

The POME used in this study was obtained from Pertubuhan Peladang Negeri Johor (PPNJ) Oil Palm Mill, Kahag, Johor, Malaysia. Table 1 shows the concentration of all parameters obtained during the characterization of Palm oil mill effluent from PPNJ given a $\mathrm{pH}$ of 4.50 which fell within the range of $4.39-4.60$ reported by [20] with an average temperature of $49.5^{\circ} \mathrm{C}$. The average values of $\mathrm{BOD}_{3}$ and COD were $24367 \mathrm{mg} / \mathrm{L}$ and $74686 \mathrm{mg} / \mathrm{L}$ respectively, and the ratio of $\mathrm{BOD}_{3} / \mathrm{COD}$ of raw POME was about 0.33 .

Table 1. Initial Characteristics of Raw POME.

\begin{tabular}{|c|c|c|c|c|c|}
\hline Parameter & Conc & Parameter & Conc. & Parameter & Conc. \\
\hline $\mathrm{pH}$ & 4.50 & COD & 7223 & $\mathrm{Mn}(\mathrm{mg} / \mathrm{L})$ & 8.216 \\
\hline Temperature ${ }^{\circ} \mathrm{C}$ & 49.5 & $\mathrm{BOD}_{3} / \mathrm{COD}$ & 0.33 & $\mathrm{Fe}(\mathrm{mg} / \mathrm{L})$ & 63.14 \\
\hline TDS (mg/L) & 4595 & Colour (Pt. Co) & 8021 & $\mathrm{Al}(\mathrm{mg} / \mathrm{L})$ & 7.933 \\
\hline TSS (mg/L) & 2673 & $\mathrm{NH}_{3}-\mathrm{N}(\mathrm{mg} / \mathrm{L})$ & 520.6 & $\mathrm{Cu}(\mathrm{mg} / \mathrm{L})$ & 0.823 \\
\hline Turbidity (NTU) & 2658 & Oil \& Grease $(\mathrm{mg} / \mathrm{L})$ & 7310 & $\mathrm{~Pb}(\mathrm{mg} / \mathrm{L})$ & 0.026 \\
\hline $\mathrm{BOD}_{3}(\mathrm{mg} / \mathrm{L})$ & 2387 & $\mathrm{Zn}(\mathrm{mg} / \mathrm{L})$ & 3.554 & $\mathrm{Cd}(\mathrm{mg} / \mathrm{L})$ & 0.007 \\
\hline
\end{tabular}

\subsection{Analytical Method}

Analysis of chemical oxygen demand (COD), ammoniacal nitrogen, oil and grease, turbidity, colour, total suspended solids (TSS) and heavy metals $(\mathrm{Pb}, \mathrm{Mn}, \mathrm{Fe}, \mathrm{Cu}, \mathrm{Zn})$ removal following standard methods [21] was carried out on the wastewater.

\subsubsection{Chemical Oxygen Demand (COD) (USEPA Method 8000)}

In this study, Chemical Oxygen Demand (COD) was analyzed using $\mathrm{HACH}$ Method. Four HACH test tubes were prepared consisting of concentrated sulphuric acid, potassium dichromate and distilled water. The first test tube was used as blank while the other three were used as sample run repetition. The samples were diluted with a dilution factor of $50.2 \mathrm{~mL}$ of distilled water would be added into the first test tubes as blank and $2 \mathrm{~mL}$ of diluted sample would be added into each of the three test tubes. The mixture of each four test tube would then be refluxed for 2 hours after which the oxidant used up by the organic and inorganic substances in the sample would be determined by colorimetric measurements. The COD content of the sample in $\mathrm{mg} / \mathrm{L}$ would be read directly using DR 6000 Spectrophotometer. Hence, the COD reduction efficiency was determined by:

COD reduction efficiency $(\%)=$ COD final discharge POME - COD after treatment x $100 \%$ 


\section{COD final discharge POME}

\subsubsection{Turbidity (Standard Method 2130B)}

The turbidity measurement was carried out on wastewater sample (POME) using DR/2010 Portable Data logging Spectrophotometer at $750 \mathrm{~nm}$. The measurement was based on the light-transmitting properties of the wastewater. For blank, distilled water were used in a $25 \mathrm{~mL}$ sample cell and first inserted into the spectrophotometer to calibrate. The same volume of wastewater sample in another sample cell was inserted into DR/2010 Portable Datalogging Spectrophotometer and read at $860 \mathrm{~nm}$. This analysis was made before and after each treatment. Turbidity removal efficiency was then determined by:

Turbidity removal $(\%)=$ Turbidity final discharge POME - Turbidity after treatment x $100 \%$

Turbidity final discharge POME

\subsection{3. pH (APHA Standard Method 4500)}

Initial and subsequent $\mathrm{pH}$ tests were carried out according to the Standard Method [21]. HQ440d HACH pH meter was used to determine the $\mathrm{pH}$ of the POME sample before and after the treatment. For the determination of initial $\mathrm{pH}$ for the coagulation process, sulphuric acid $\left(\mathrm{H}_{2} \mathrm{SO}_{4}\right)$ and sodium hydroxide $(\mathrm{NaOH})$ solutions were used to get the desired $\mathrm{pH}$ value.

\subsubsection{Total Suspended Solid (TSS) (Standard Method 2540D)}

The experiment began by preparing the GAST DOAP404-BN filtration apparatus. $5 \mathrm{~mL}$ of the raw POME sample was used for the filtration. Suction of the effluent also began and followed by stirring of the sample with a magnetic stirrer at a speed that would shear larger particles. Stopwatch was used to measure the amount of time it takes for the sample water to flow through the filter. The filter was then carefully removed from the filtration apparatus, dried for at least 1 hour at 103 to $105^{\circ} \mathrm{C}$ in an oven, cooled in a desiccator to balance the temperature and was finally transferred to the aluminium weighing dish for weighing.

The concentration of total suspended solids in the sample was be obtained by the given formula below:

Total suspended solids, $\mathrm{mg} / \mathrm{L}=\frac{(\mathrm{A}-\mathrm{B}) \times 1000}{(\text { Sample vol.mL })}$

Where:

$\mathrm{A}=$ Sample and filter weight, $\mathrm{mg}$

$\mathrm{B}=$ Filter weight, $\mathrm{mg}$

\subsubsection{Ammoniacal Nitrogen (Nessler Method, USEPA Method 8038)}

Ammoniacal nitrogen in $\mathrm{mg} / \mathrm{L}$ present in the effluent was determined by Nessler's method, using DR $6000 \mathrm{HACH}$ spectrophotometer. Distilled water was be used as a blank for ammonia measurements. The experiment began by filling a graduated cylinder with $25 \mathrm{~mL}$ of the wastewater sample after dilution. Another graduated cylinder was also be filled with $25 \mathrm{~mL}$ of distilled water in another mixing graduated cylinder as the blank. Three drops of Mineral Stabilizer would be added to each cylinder and put upside down several times to mix. Three drops of Polyvinyl Alcohol Dispersing Agent was also added to each cylinder by holding the dropping bottle vertically and mixed them. $1.0 \mathrm{~mL}$ of Nessler reagent was then be pipetted into each cylinder and mixed several times. Each solution was poured into a sample cell and the results were taken by DR 6000.

\subsubsection{Oil and Grease (Hexane Extractable Gravimetric Method, USEPA Method 10056)}

An experiment was conducted to evaluate the performance of petroleum ether in the extraction of residual oil from POME. The original and treated POME samples were transferred to a separating funnel and $30 \mathrm{~mL}$ of petroleum ether was introduced into the separating funnel. The contents were shaken vigorously for $2 \mathrm{~min}$ and allowed to separate into layers for $5 \mathrm{~min}$. The aqueous layer was then drip drained into a conical flask. Extractions were repeated twice with two more portions of $30 \mathrm{~mL}$ petroleum ether. The solvent layer was then drained through a funnel containing filter paper and $2 \mathrm{~g}$ of anhydrous sodium sulphate, both of which had been solvent-rinsed, into a clean conical flask. The solvent was distilled off using the rotary evaporator. The drying was completed in the oven at $103^{\circ} \mathrm{C}$ for 5 to 10 minutes. The flask was cooled in a desiccator for about 30 min and weighed. The drying and cooling steps were repeated until the weight becomes constant to calculate the concentration of residual oil extracted. The concentration of residual oil extracted with petroleum ether was used for the analysis.

\subsubsection{Colour (USEPA, Method 8025)}

The colour of raw POME for both the influent and effluent were measured by the standard platinum-cobalt method using DR $6000 \mathrm{HACH}$ spectrophotometer. For testing colour, two test tubes were prepared, deionised water was poured in one test tube and used as control while the diluted wastewater sample was poured in the other test tube. The Hach method program number 125 corresponding to colour measurement at wavelength $465 \mathrm{~nm}$ was then selected after inserting each of the test tubes in the cell holder followed by pressing zero to get $0 \mathrm{Pt}$. Co for the control and pressing read for the colour measurement of the second test tube containing wastewater.

\subsubsection{Heavy Metals}

The determination of heavy metals concentration in POME was carried out using an Atomic Absorption Spectrometer (AAS) and Inductively Coupled Plasma (ICP). To begin the AAS analysis, substance were first dissolved in a liquid, dried and then atomized to vaporize the substance into gas atoms. Sample were prepared by adding $5 \%$ of nitric acid and refluxed at $95^{\circ} \mathrm{C}$ for 15 minutes. Samples were then filtered with a filter paper. Standard solutions were prepared for Al, $\mathrm{Zn}, \mathrm{Fe}, \mathrm{Cd}, \mathrm{Pb}, \mathrm{Cu}$ and $\mathrm{Mn}$ all based on the permissible limit concentration.

\subsubsection{Sludge Volume Percentage}

The sludge volume percentage was determined by measuring the sludge height after each electrocoagulation 
process which is 30 minutes of settling time. The recorded sludge heights then were determined by doing simple calculation to get the percentages of sludge volume. The diameter of the beaker which is $11 \mathrm{~cm}$ were taken into account as well as the height of the sample after being poured into the beaker at the beginning of the process which is also $11 \mathrm{~cm}$.

$$
\% \text { Sludge Volume }=\frac{\mathrm{A} \times \mathrm{H} 1 \mathrm{x}}{\mathrm{A} \times \mathrm{H} 2} \times 100 \%
$$

Where;

$\mathrm{A}=$ Cross sectional area of the $1 \mathrm{~L}$ beaker $=\left(\pi \mathrm{d}^{2}\right) / 4 ; \mathrm{d}=$ diameter of the beaker $=11 \mathrm{~cm}$

$\mathrm{H}_{1}=$ Height of sludge after 30 minutes settling time

$\mathrm{H}_{2}=$ Height of POME sample in the $1 \mathrm{~L}$ beaker $(11 \mathrm{~cm})$

\section{Result Analysis and Discussions}

\subsection{Settleability of Raw POME}

Palm oil mill effluent from PPNJ was found to contain high values of TSS and TDS which implies that the sample is capable of producing high sludge. Hence, this study investigated the setleability of the raw sample at different time interval thereby measuring sludge height and calculating the percentage sludge volume as in Figure 1. Raw POME was kept to settle for several minutes where readings of the supernatant were taken to mark the sludge height at an interval of 60 minutes. It was observed that sludge volume decreases as the minute's increases and was almost constant at 240 minutes.

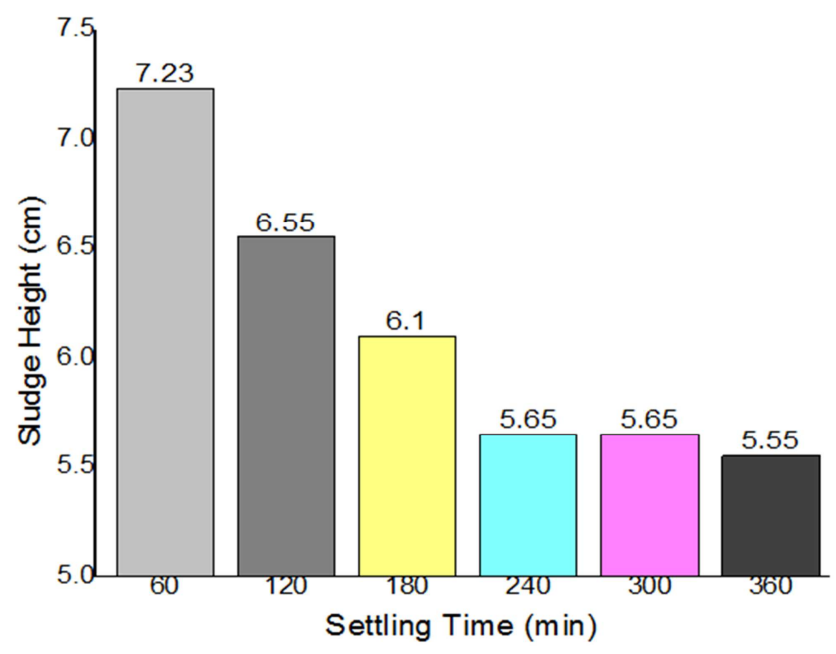

Figure 1. Settleability of raw POME

\subsection{Optimization for Various Combinations}

\subsubsection{Optimum dose of $\mathrm{ALUM}+\mathrm{FeCl}_{3}$}

Combination of different doses of Alum with $1 \mathrm{~g} / \mathrm{L}$ dose of ferric chloride showed significant in pollutants load reduction in POME as can be seen Figure 2, $2 \mathrm{~g} / \mathrm{L}$ alum $+1 \mathrm{~g} / \mathrm{L} \mathrm{Fecl}_{3}$ provides the highest removal percentages of colour, $\mathrm{NH}_{3}-\mathrm{N}$, oil \& grease, $\mathrm{Pb}, \mathrm{Cd}$ and $\mathrm{Zn}$ as $79.67 \%, 98.54 \%, 97.28 \%$,
$95.95 \%, 95.39 \%$ and $92.10 \%$ respectively while $77.65 \%$ $\mathrm{COD}$ removal was reached at $3 \mathrm{~g} / \mathrm{L}$ alum $+1 \mathrm{~g} / \mathrm{L} \mathrm{FeCl}_{3}$ with not much variance compared to $75.52 \%$ obtained at $2 \mathrm{~g} / \mathrm{L}$ alum $+1 \mathrm{~g} / \mathrm{L} \mathrm{FeCl}_{3} .99 .59 \%, 86.05 \%$ and $92.19 \%$ removals were achieved for TSS, $\mathrm{Cu}$ and $\mathrm{Mn}$ respectively at combination dose of $1 \mathrm{~g} / \mathrm{L}$ alum $+1 \mathrm{~g} / \mathrm{L} \mathrm{FeCl}_{3}$. Turbidity removal was best at $4 \mathrm{~g} / \mathrm{L}$ alum $+1 \mathrm{~g} / \mathrm{L} \mathrm{FeCl}_{3}$ with an efficiency of $99.18 \% .2 \mathrm{~g} / \mathrm{L}$ alum $+1 \mathrm{~g} / \mathrm{L} \mathrm{FeCl}_{3}$ combination dose with $21.25 \%$ as the percentage sludge volume is chosen as the optimum combination dose since most parameters performed better at the dose.

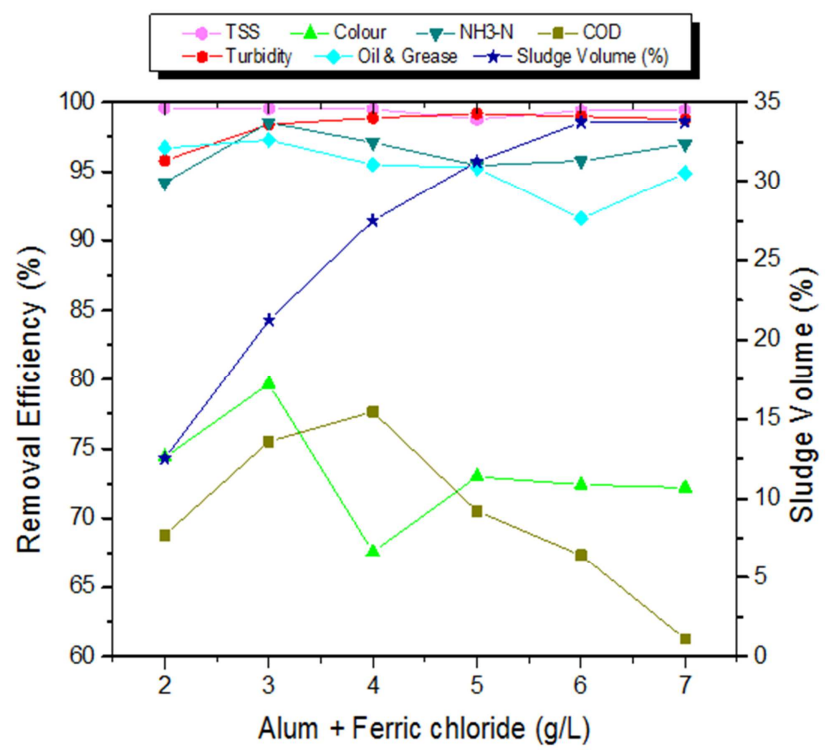

(a)

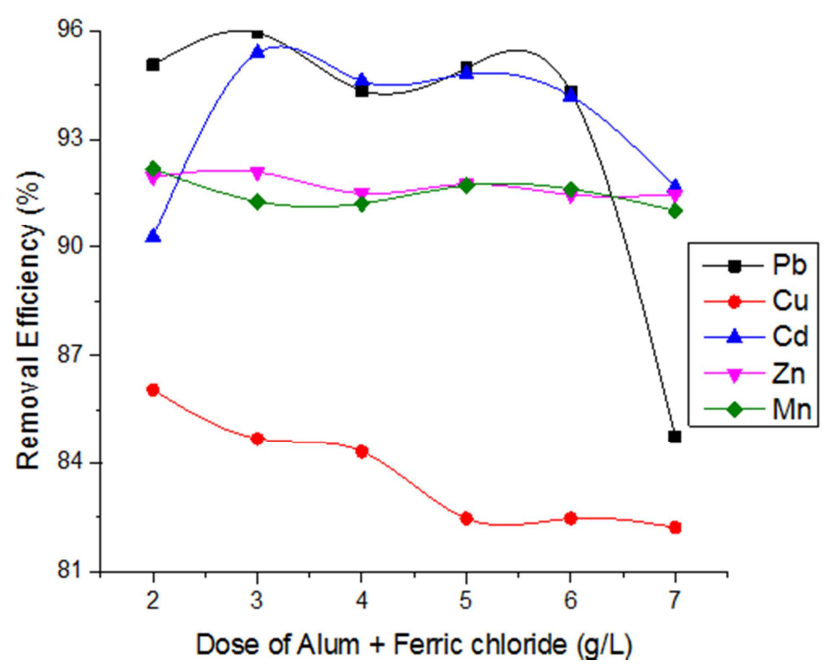

(b)

Figure 2. Removal percentage of (a) TSS, turbidity, oil \& grease, colour, $\mathrm{COD}$ and $\mathrm{NH}_{3}-\mathrm{N}$ as well as sludge volume percentage and (b) $\mathrm{Pb}, \mathrm{Cu}, \mathrm{Cd}$, $\mathrm{Zn}$ and $\mathrm{Mn}$ for $1 \mathrm{~g} / \mathrm{L}-6 \mathrm{~g} / \mathrm{L}$ dose of alum incorporating $1 \mathrm{~g} / \mathrm{L}_{\text {of }} \mathrm{FeCl}_{3}$ to each dose at pH 4.51, $250 \mathrm{rpm}$ rapid mixing speed for 3 minutes, $30 \mathrm{rpm}$ slow mixing speed for 30 minutes and 60 minutes settling time.

\subsubsection{Optimum dose of Alum + Chitosan}

Results seen in Figure 3 proved that the combination of alum + chitosan at variable doses increases the removal 
efficiency until the optimum dose was reached where the removal efficiency start to decrease. $3 \mathrm{~g} / \mathrm{L}$ alum $+0.4 \mathrm{~g} / \mathrm{L}$ chitosan as reported by [22] also provides the highest removal percentages of TSS, colour, oil \& grease, $\mathrm{COD}, \mathrm{Pb}$, $\mathrm{Cu}, \mathrm{Cd}$ and $\mathrm{Fe}$ as $99.69 \%, 95.24 \%, 95.63 \%, 70.12 \%$, $97.65 \%, 83.95 \%, 95.00 \%$ and $92.23 \%$ while $98.04 \% \mathrm{NH}_{3}-\mathrm{N}$ removal was reached at $4 \mathrm{~g} / \mathrm{L}$ alum $+0.4 \mathrm{~g} / \mathrm{L}$ chitosan even though $97.26 \%$ was at $3 \mathrm{~g} / \mathrm{L}$ alum $+0.4 \mathrm{~g} / \mathrm{L}$ chitosan. Therefore $97.26 \%$ would be considered since it has the lower dose. Turbidity and $\mathrm{Zn}$ with removal efficiencies of $99.61 \%$ and $91.57 \%$ were best at $2 \mathrm{~g} / \mathrm{L}$ alum $+0.4 \mathrm{~g} / \mathrm{L}$ chitosan. However, Mn removal efficiency continuously increases as combination dose is being increased up to the last dose of 6 $\mathrm{g} / \mathrm{L}$ alum $+0.4 \mathrm{~g} / \mathrm{L}$ chitosan which obtained $93.45 \%$ removal. More so, least percentage sludge volume of $31.25 \%$ was achieved at $3 \mathrm{~g} / \mathrm{L}$ alum $+0.4 \mathrm{~g} / \mathrm{L}$ chitosan, hence it becomes the optimum combination dose.

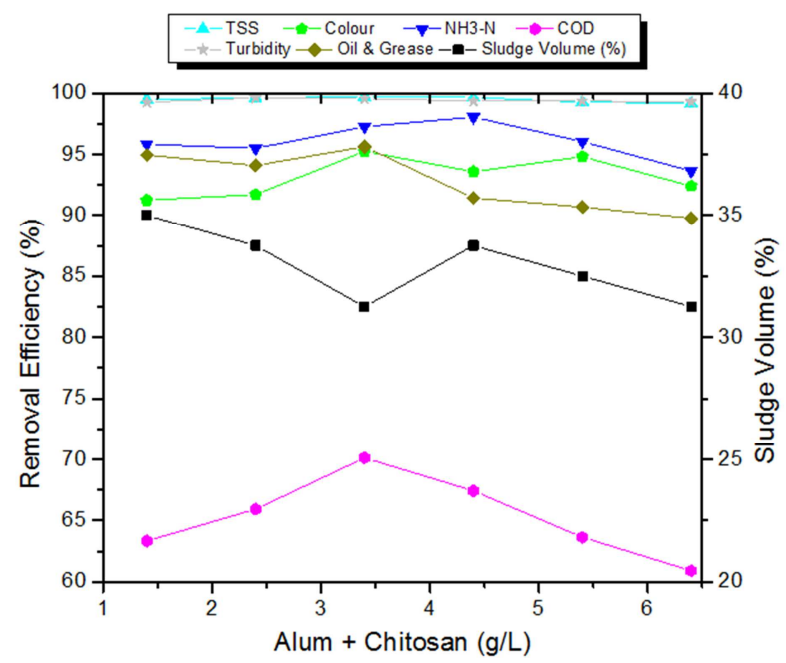

(a)

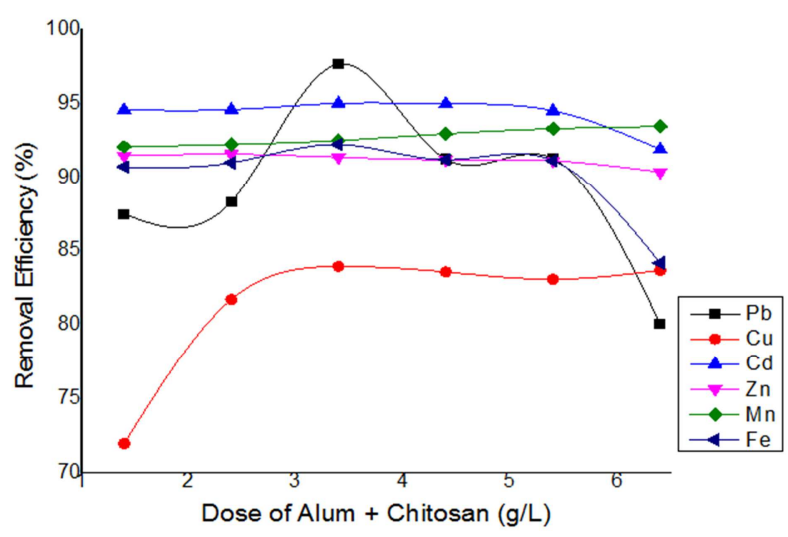

(b)

Figure 3. Removal percentage of (a) TSS, turbidity, oil \& grease, colour, $\mathrm{COD}$ and $\mathrm{NH}_{3}-\mathrm{N}$ as well as sludge volume percentage and (b) $\mathrm{Pb}, \mathrm{Cu}, \mathrm{Cd}$, $\mathrm{Zn}, \mathrm{Mn}$ and $\mathrm{Fe}$ for $1 \mathrm{~g} / \mathrm{L}-6 \mathrm{~g} / \mathrm{L}$ dose of alum incorporating $0.4 \mathrm{~g} / \mathrm{L}$ of chitosan to each dose at $p H$ 4.51,250 rpm rapid mixing speed for 3 minutes, 30 rpm slow mixing speed for 30 minutes and 60 minutes settling time.

\subsubsection{Optimum dose of Alum + Zeolite}

Combination of different doses of alum with $1 \mathrm{~g} / \mathrm{L}$ dose of zeolite showed removal efficiencies of TSS, turbidity, oil \& grease, colour, $\mathrm{NH}_{3}-\mathrm{N}, \mathrm{COD}, \mathrm{Pb}, \mathrm{Cd}, \mathrm{Cu}, \mathrm{Zn}$ Fe and $\mathrm{Mn}$ as well as sludge volume percentage in the POME as can be seen in Figure 4. $2 \mathrm{~g} / \mathrm{L}$ alum $+1 \mathrm{~g} / \mathrm{L}$ zeolite provides the highest removal percentages of TSS, colour, $\mathrm{NH}_{3}-\mathrm{N}, \mathrm{COD}, \mathrm{Pb}, \mathrm{Cd}$ and Mn as $99.33 \%, 94.62 \%, 96.73 \%, 68.72 \%, 78.88 \%, 93.07 \%$ and $91.69 \%$ respectively with $92.41 \%$ and $98.32 \%$ removal at $3 \mathrm{~g} / \mathrm{L}$ alum $+1 \mathrm{~g} / \mathrm{L}$ zeolite for oil \& grease and turbidity respectively. $\mathrm{Cu}$ removal efficiency was found to be increasing as combination dose is being increased up to the $5^{\text {th }}$ combination dose of $5 \mathrm{~g} / \mathrm{L}$ alum $+1 \mathrm{~g} / \mathrm{L}$ zeolite which obtained $89.14 \%$ removal where $91.68 \%$ and $87.75 \%$ removals for $\mathrm{Zn}$ and $\mathrm{Fe}$ were obtained at the $1^{\text {st }}$ combination dose of $1 \mathrm{~g} / \mathrm{L}$ alum $+1 \mathrm{~g} / \mathrm{L}$ zeolite and continue to decrease as the dose is being increased indicating that the combination dose is not suitable for their removal. Hence, $2 \mathrm{~g} / \mathrm{L}$ alum $+1 \mathrm{~g} / \mathrm{L}$ zeolite with $8.75 \%$ as percentage sludge volume is found to be the optimum combination dose for this experiment.

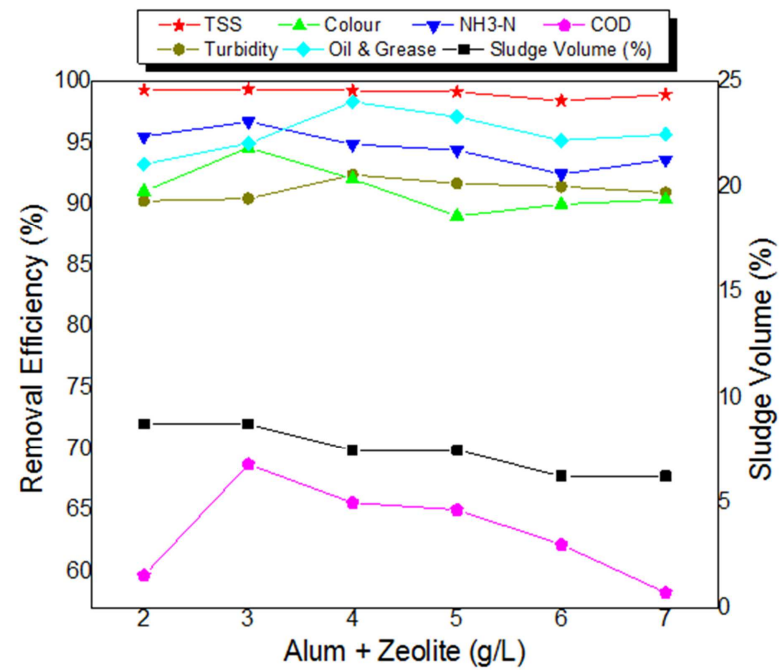

(a)

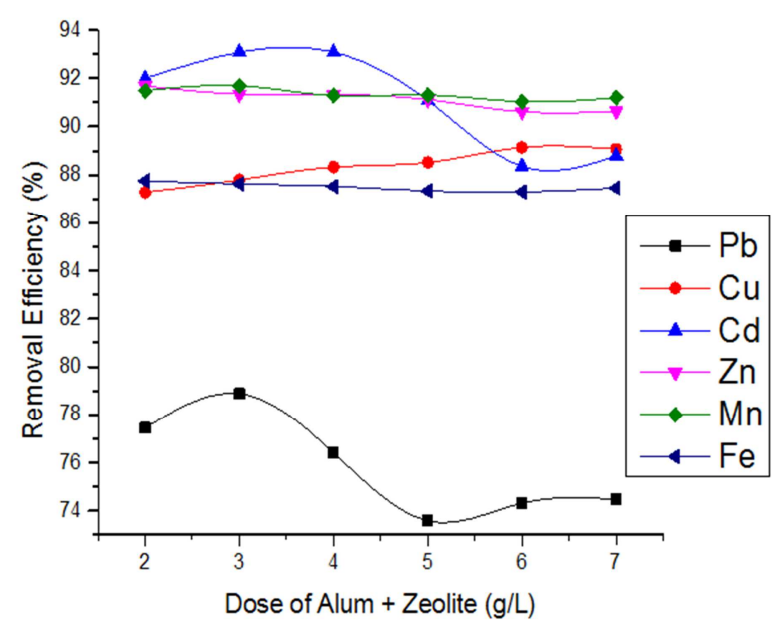

(b)

Figure 4. Removal percentage of (a) TSS, turbidity, oil \& grease, colour, $\mathrm{COD}$ and $\mathrm{NH}_{3}-\mathrm{N}$ as well as sludge volume percentage and (b) $\mathrm{Pb}, \mathrm{Cu}, \mathrm{Cd}$, $\mathrm{Zn}, \mathrm{Mn}$ and $\mathrm{Fe}$ for $1 \mathrm{~g} / \mathrm{L}-6 \mathrm{~g} / \mathrm{L}$ dose of alum incorporating $1 \mathrm{~g} / \mathrm{L}$ of zeolite to each dose at $\mathrm{pH}$ 4.51, $250 \mathrm{rpm}$ rapid mixing speed for 3 minutes, $30 \mathrm{rpm}$ slow mixing speed for 30 minutes and 60 minutes settling time. 


\subsubsection{Optimum dose of Alum + Moringa Oleifera}

Results shown in Figure 5 indicates that the combination of alum + moringa oleifera at variable doses of alum increases the removal efficiency until the optimum dose was reached where the removal efficiency start to decrease. $4 \mathrm{~g} / \mathrm{L}$ alum $+2 \mathrm{~g} / \mathrm{L}$ moringa oleifera provides the highest removal percentages of TSS, $\mathrm{NH}_{3}-\mathrm{N}$, oil \& grease, $\mathrm{COD}, \mathrm{Cu}, \mathrm{Cd}$ and $\mathrm{Zn}$ as $97.19 \%, 89.98 \%, 87.32 \%, 69.17 \%, 86.42 \%, 95.16 \%$, $91.85 \%$ respectively. $96.13 \%$ and $93.98 \%$ removal at $3 \mathrm{~g} / \mathrm{L}$ alum $+2 \mathrm{~g} / \mathrm{L}$ moringa oleifera and $5 \mathrm{~g} / \mathrm{L}$ alum $+2 \mathrm{~g} / \mathrm{L}$ moringa oleifera were achieved for colour and $\mathrm{Pb}$ respectively. $\mathrm{Mn}$ and $\mathrm{Fe}$ with $93.98 \%$ and $96.06 \%$ removals respectively were obtained at the last combination dose signifying that they require higher combination dose for effective removal while $91.40 \%$ turbidity removal was achieved at the initial combination dose. Thus, it can be concluded that alum + moringa oleifera combination is not suitable for turbidity removal. From the results obtained for this experiment, it can be concluded that $4 \mathrm{~g} / \mathrm{L}$ alum $+2 \mathrm{~g} / \mathrm{L}$ moringa oleifera with $13.75 \%$ as percentage sludge volume is the optimum combination dose.

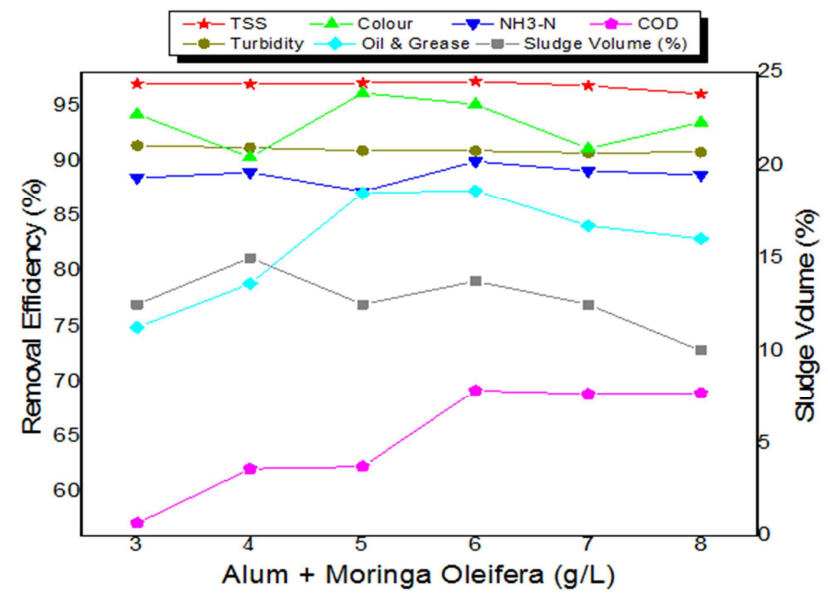

(a)

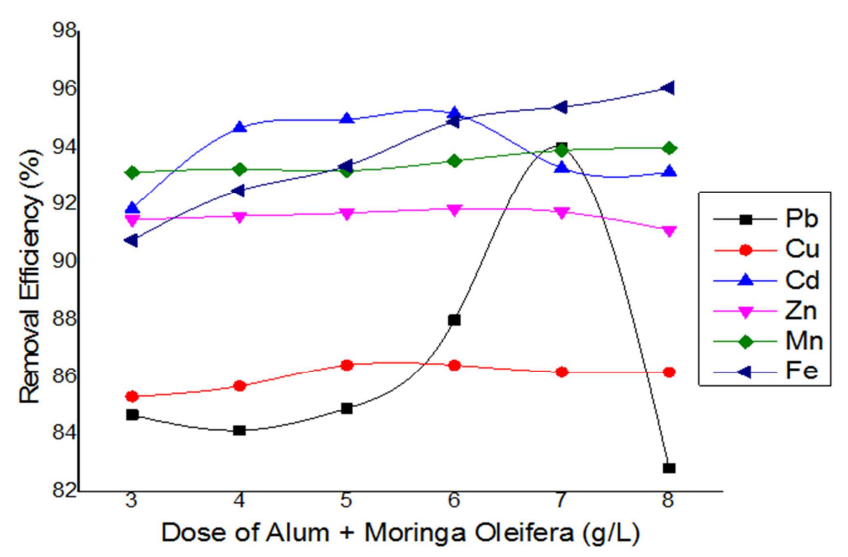

(b)

Figure 5. Removal percentage of (a) TSS, turbidity, oil \& grease, colour, $\mathrm{COD}$ and $\mathrm{NH}_{3} \mathrm{~N}$ as well as sludge volume percentage and (b) $\mathrm{Pb}, \mathrm{Cu}, \mathrm{Cd}$, $\mathrm{Zn}, \mathrm{Mn}$ and Fe for $1 \mathrm{~g} / \mathrm{L}-6 \mathrm{~g} / \mathrm{L}$ dose of alum incorporating $2 \mathrm{~g} / \mathrm{L}$ of moringa oleifera to each dose at $p H 4.51,250 \mathrm{rpm}$ rapid mixing speed for 3 minutes, 30 rpm slow mixing speed for 30 minutes and 60 minutes settling time.

\subsubsection{Comparison of Optimum dose for Various Coagulants Combinations}

Results obtained from laboratory experiments proved that addition of $1 \mathrm{~g} / \mathrm{L}$ of ferric chloride, $0.4 \mathrm{~g} / \mathrm{L}$ chitosan and $1 \mathrm{~g} / \mathrm{L}$ zeolite each to different dose of alum, were able to reduce alum dose from $4 \mathrm{~g} / \mathrm{L}$ to $2 \mathrm{~g} / \mathrm{L}, 3 \mathrm{~g} / \mathrm{L}$ and $2 \mathrm{~g} / \mathrm{L}$ respectively. However, $2 \mathrm{~g} / \mathrm{L}$ moringa oleifera addition could not reduce alum dose as high removal efficiencies for most parameters was obtained at 4 $\mathrm{g} / \mathrm{L}$ alum $+2 \mathrm{~g} / \mathrm{L}$ moringa oleifera. On the sludge volume reduction, Figure $6 \mathrm{a}$ indicates that zeolite is the best in sludge reduction with the least sludge volume of $11.25 \%$ followed by alum with $12.50 \%$ and it was further reduced to $8.75 \%$ by a combination of $2 \mathrm{~g} / \mathrm{L}$ alum $+1 \mathrm{~g} / \mathrm{L}$ zeolite.

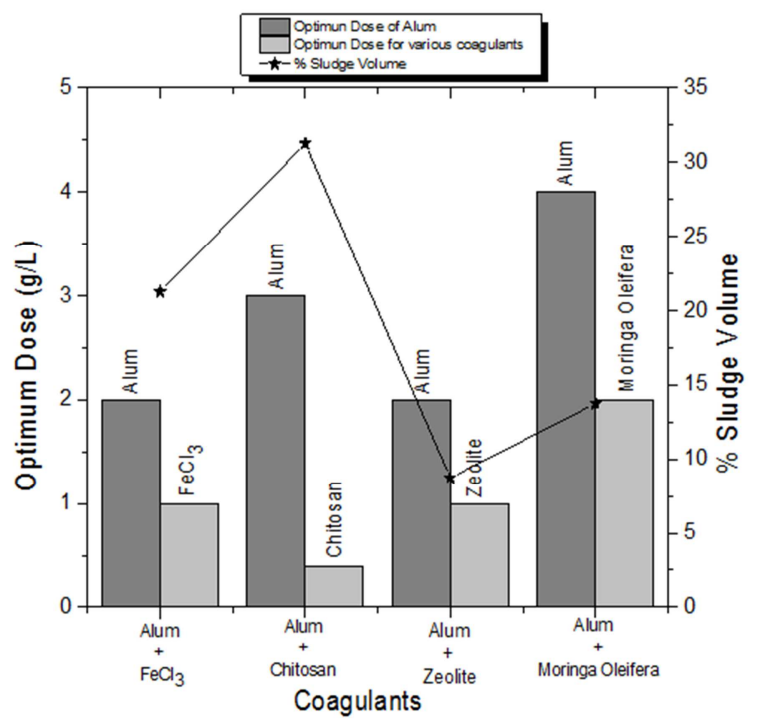

(a)

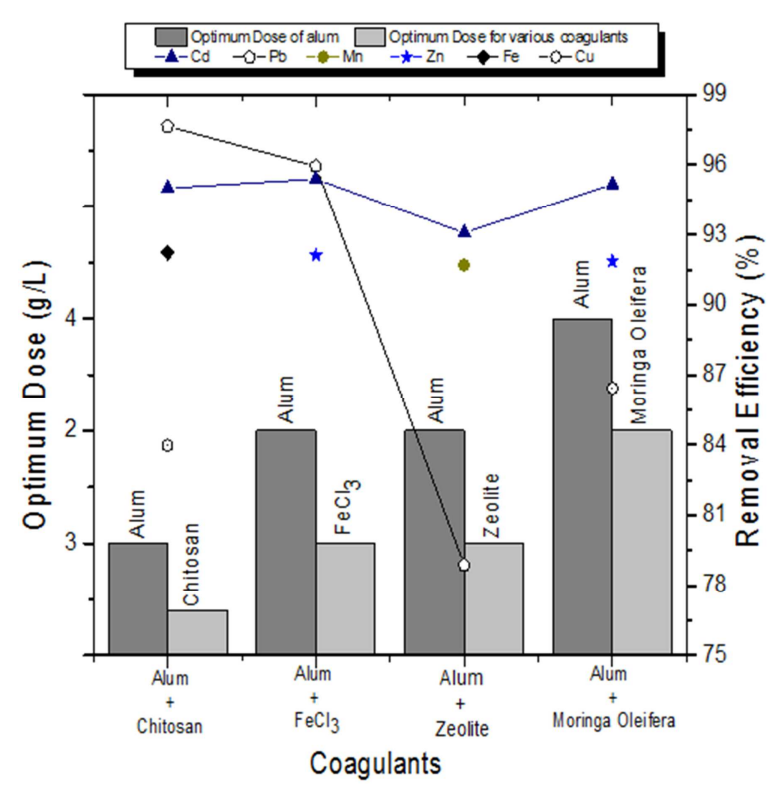

(b)

Figure 6. Comparison of optimum dose combinations for optimum removal of (a) TSS, turbidity, oil \& grease, colour, $\mathrm{COD}$ and $\mathrm{NH}_{3} \mathrm{~N}$ alongside (b) some heavy metals of $\mathrm{Pb}, \mathrm{Cu}, \mathrm{Cd}, \mathrm{Mn}, \mathrm{Zn}$ and $\mathrm{Fe}$ with sludge volume percentage. 
The performance of heavy metals reduction improved when alum was combined with various coagulants as shown below in Figure $6 \mathrm{~b}$ where $2 \mathrm{~g} / \mathrm{L}$ alum $+1 \mathrm{~g} / \mathrm{L} \mathrm{FeCl}_{3}$ obtain $95.95 \%, 95.39 \%$ and $92.10 \%$ as highest removals for $\mathrm{Pd}, \mathrm{Cd}$ and $\mathrm{Zn}$ respectively. Combined coagulants dose of $3 \mathrm{~g} / \mathrm{L}$ alum $+0.4 \mathrm{~g} / \mathrm{L}$ chitosan removed $\mathrm{Pb}, \mathrm{Cu}, \mathrm{Cd}$ and $\mathrm{Fe}$ at efficiencies of $97.65 \%, 83.95 \%, 95.00 \%$ and $92.23 \%$ respectively. When $2 \mathrm{~g} / \mathrm{L}$ alum was combined with $1 \mathrm{~g} / \mathrm{L}$ zeolite, three metals $(\mathrm{Pb}, \mathrm{Cd}$ and $\mathrm{Mn}$ with $78.88 \%, 93.07 \%$ and $91.69 \%$ ) recorded high performance compared to when zeolite was used alone with two metals achieving high removals. The use of an anionic polymer as a flocculent together with the combination of $4 \mathrm{~g} / \mathrm{L}$ alum and $2 \mathrm{~g} / \mathrm{L}$ moringa oleifera has greatly improved the performance of moringa oleifera in the coagulation of POME as $86.42 \%$, $95.16 \%$ and $91.85 \%$ removals were obtained for $\mathrm{Cu}, \mathrm{Cd}$ and $\mathrm{Zn}$ respectively.

Tables 2 and Table 3 shows that $3 \mathrm{~g} / \mathrm{L}$ alum $+0.4 \mathrm{~g} / \mathrm{L}$ chitosan combination achieved excellent parameter reductions and as well the highest for $\mathrm{Pb}$, TSS and turbidity as $97.65 \%, 99.69 \%$ and $99.61 \%$ respectively. The parameter reductions of $95.39 \%, 92.10 \%, 98.04 \%$ and $77.65 \%$ were achieved for $\mathrm{Cd}, \mathrm{Zn}, \mathrm{NH}_{3}-\mathrm{N}$ and COD when $2 \mathrm{~g} / \mathrm{L}$ alum +1 $\mathrm{g} / \mathrm{L} \mathrm{FeCl}_{3}$ were combined. Combined dose of $2 \mathrm{~g} / \mathrm{L}$ alum +1 $\mathrm{g} / \mathrm{L}$ zeolite gave the highest $\mathrm{Cu}$ and oil \& grease removal of $89.14 \%$ and $98.32 \%$ while $4 \mathrm{~g} / \mathrm{L}$ alum $+2 \mathrm{~g} / \mathrm{L}$ moringa oleifera was the best $\mathrm{Mn}, \mathrm{Fe}$ and colour removal at efficiencies of $93.98 \%, 96.06 \%$ and $96.13 \%$ respectively.

Table 2. Parameters removal for various coagulant combination.

\begin{tabular}{llllll}
\hline \multirow{2}{*}{ Coagulants } & \multicolumn{2}{l}{ Parameters removal efficiency (\%) } & & & \\
\cline { 2 - 6 } & TSS & Turbidity & NH $_{\mathbf{3}}$-N & COD & Colour \\
\hline Alum + Chitosan & 99.69 & 99.61 & 98.04 & 70.12 & 95.24 \\
Alum + M. O. & 97.19 & 91.40 & 89.98 & 69.17 & 96.13 \\
Alum + FeC13 & 99.59 & 99.18 & 98.54 & 77.65 & 79.67 \\
Alum + Zeolite & 99.33 & 92.41 & 96.73 & 68.72 & 97.32 \\
\hline
\end{tabular}

Table 3. Heavy metals removal for various coagulant combination.

\begin{tabular}{llllll}
\hline \multirow{2}{*}{ Coagulants } & \multicolumn{2}{l}{ Parameters removal efficiency (\%) } & & & \\
\cline { 2 - 6 } & Pb & Cu & Cd & Zn & \\
\hline Alum + Chitosan & 97.65 & 83.95 & 95.0 & 91.6 & 93.5 \\
Alum + M. O. & 93.98 & 86.42 & 95.2 & 91.9 & 92.2 \\
Alum + FeCl & 95.95 & 86.05 & 95.4 & 92.1 & 94.0 \\
Alum + Zeolite & 78.88 & 89.14 & 93.1 & 91.7 & 92.2 \\
\hline
\end{tabular}

\section{Conclusion}

This study was aimed at alum dose reduction in the treatment of POME because of its numerous effects to human and aquatic life. Thus, coagulation-flocculation method was used to examine the effectiveness alum and a combination of alum with ferric chloride, chitosan, zeolite and moringa oleifera. Series of Jar test were carried out and the comparison of coagulants under optimised conditions indicates that the best coagulant combination in terms of sludge volume reduction was alum + zeolite as the sludge volume was reduced from $12.50 \%$ to $8.75 \%$ by a combination of $2 \mathrm{~g} / \mathrm{L}$ alum $+1 \mathrm{~g} / \mathrm{L}$ zeolite. The performance of heavy metals reduction was also improved when alum was combined with various coagulants. Alum combination with other coagulants gave higher reductions for turbidity, oil \& grease, TSS, $\mathrm{NH}_{3}-\mathrm{N}, \mathrm{COD}, \mathrm{Zn}, \mathrm{Pb}, \mathrm{Cu}, \mathrm{Mn}$ and $\mathrm{Fe}$ as $99.61 \%, \quad 98.32 \%, \quad 99.69 \%, \quad 98.54 \%, \quad 77.65 \%, \quad 92.10 \%$, $97.65 \%, 89.14 \%, 93.98 \%$ and $96.06 \%$ respectively. However, all combinations were not successful in high colour and $\mathrm{Cd}$ removals as $96.44 \%$ for colour was obtained using chitosan alone while $95.75 \%$ for $\mathrm{Cd}$ using alum alone. From these obtained results, it can be concluded that treatment of POME by coagulant-flocculation technique through the combination of alum with other coagulants is effective in high effluent removal.

\section{References}

[1] M. Ammar (2015). Environmental Problems Facing My Country (Malaysia) Today.

http://amasyafiq.blogspot.com/2015/03/environmental-problemfacing-by-my.html (Accessed on March, 2015).

[2] C. Y. Yang, et al. (2003). "Arsenic in drinking water and adverse pregnancy outcome in an arseniasis-endemic area in north-eastern Taiwan."Environ. Res. 91(1): 29-34.

[3] A. L. Ahmad, S. Ismail, \& S. Bathia, (2003). Water Recycling from Palm Oil Mill Effluent (POME) Using Membrane Technology. J. Desalination 157: 87- 95.

[4] Environmental Quality (Industrial Effluent) Regulation 2009.

[5] S. L. Tong, and B. A. Jaafar, (2005). POME biogas capture, upgrading and utilisation. Proceeding of the PIPOC 2005 International Palm Oil Congress (chemistry and technology); pp. 328-36.

[6] J. Guo, and A. C. Lau (2002). "Characterization of adsorbent prepared from oil-palm shell by $\mathrm{CO}_{2}$ activation for removal of gaseous pollutants". Materials letters; 55 (5): 334-339.

[7] J. Tan, (2007). Chemical Pre-treatment for Palm Oil Mill Effluent (POME). M. Eng. Thesis, Universiti Technology Malaysia.

[8] M. I. A. Karim, and Lau L. H. (1987). The Use of Coagulant and Polymeric Flocculating Agent in the Treatment of Palm Oil Mill Effluent (POME). Biological Waste, 20: 209 - 218. 
[9] J. Peter, S. Emma, P. Marc, M. Roger, A. P. Simon and J. Bruce (2012). Comparison of coagulation performance and floc properties using a novel zirconium coagulant against traditional ferric and alum coagulants.

[10] G. K. Folkard, J. Sutherland, R. Shaw, (2000). Water clarification using Moringa oleifera seed coagulant. On electronic products: http:www.Iboro.ac.uk/well/resources/technical-briefs/ 60 .

[11] F. Renault, B. Sancey, P., M. Badot, G. Crini (2009). Chitosan for coagulation/flocculation processes - An eco-friendly approach. Polymer Journal 45: 1337-1348.

[12] B. Marcela and D. Petr (2006). Chitosan- A new type of polymer coagulant.

[13] P. Harish, K. V. Prashanth, R. N. Tharanathan (2007). Chitin/chitosan: modifications and their unlimited application - an overview. Trends Food Sci Technol; 18: 11731 .

[14] J. K. Fatombi, B. Lartiges, T. Aminou, O. Barres, C. Caillet (2013). A natural coagulant protein from copra (Cocos nucifera): isolation, characterization, and potential for water purification. Sep. Purif. Technol. 116: 35-40.

[15] C. M. Teixeira, F. V. Kirste, P. C. N. Teixeira (2012). Evaluation of Moringa oleifera seed flour as a flocculating agent for potential biodiesel producer microalgae. J. Appl. Phycol. 24: 557-563.

[16] T. Jingxi, M. Jiang, H. Li , S. Zhang, X. Zhang (2015), A comparison between moringa oleifera seed presscake extract and polyaluminum chloride in the removal of direct black 19 from synthetic wastewater. Industrial Crops and Products (74) $530-534$.

[17] S. Bhatia, Z. Othman and A. L. Ahmad (2007b). Coagulationflocculation process for POME treatment using Moringa oleifera seeds extract: Optimization studies. Chemical Engineering Journal. 133(1): 205-212.

[18] A. M. Abdelaal, (2004). Using a natural coagulant for treating wastewater. Eighth International Water Technology Conference, IWTC8, Alexandria, Egypt.

[19] M. Syafalni, A. Rohana, A. Ismail \& N. I. Aimi (2013). Wastewater treatment using bentonite, the combinations of bentonite-zeolite, bentonite-alum, and bentonite-limestone as adsorbent and coagulant. International Journal of Environmental Sciences, 4(3): 379-391.

[20] P. Chantaraporn, M. Juntipa, I. Kanita and N. Boonyarit (2010). Pretreatment of palm oil mill effluent by electrocoagulation and coagulation. ScienceAsia (36) 142149 .

[21] APHA (2005). Standard Method for the Examination of Water and Wastewater. American Public Health Association, Washington. $21^{\text {st }}$ Edition.

[22] A. H. Mohd. \& H. P. Mohd (2007). Pre-treatment of Palm Oil Mill Effluent (POME): A Comparative Study Using Chitosan and Alum. Malaysian Journal of Civil Engineering 19(2): 385 . 